\title{
Coaching and Mentoring as a Teaching Supervision Approach in Secondary School
}

\author{
Azrani Mohd Zain \\ Department of Foundation of Education, Faculty of Educational Studies \\ Universiti Putra Malaysia, 43400 UPM Serdang, Selangor, Malaysia \\ Soaib Asimiran* \\ Department of Foundation of Education, Faculty of Educational Studies \\ Universiti Putra Malaysia, 43400 UPM Serdang, Selangor, Malaysia
}

\begin{abstract}
Abu Bakar Razali
Department of Language and Humanities Education, Faculty of Educational Studies

Universiti Putra Malaysia, 43400 UPM Serdang, Selangor, Malaysia
\end{abstract}

Nor Aniza Ahmad

Department of Foundation of Education, Faculty of Educational Studies

Universiti Putra Malaysia, 43400 UPM Serdang, Selangor, Malaysia

Received: Oct. 8, 2021 Accepted: Nov. 15, 2021 Online published: Nov. 22, 2021

doi:10.5296/ijhrs.v11i4S.19233 URL: https://doi.org/10.5296/ijhrs.v11i4S.19233

\begin{abstract}
Teaching supervision is an effective assessment tool to ensure effective teaching and learning in the classroom. Effective teaching supervision refers to the appropriate approaches taken by supervisors to supervise teachers in the classroom. In this light, the coaching and mentoring approach is a form of teaching supervision that increases the effectiveness of teaching supervision in schools. However, this approach requires an in-depth understanding of aspects related to coaching and mentoring. Thus, this study aims to examine the implementation of coaching and mentoring as a teaching supervision practice among Secondary School
\end{abstract}


principals. This study focuses on two main objectives, first, examining supervisors' understanding of coaching and mentoring, and second, identifying the extent of supervisors' readiness towards implementing the coaching and mentoring approach as a teaching supervision practice. This study adopted the qualitative exploratory research design and involved eight samples selected by purposive sampling. Interviews, observation and document analysis were used as the main tools in collecting the study data. The data collected were analysed using i) in-depth reading, ii) open coding, and iii) axial coding. The study's findings indicate that ineffective teaching and learning practices have contributed to declining student academic achievement. In this regard, ineffective teaching and learning practices are attributed to teachers' failure to adopt effective teaching techniques and the lack of curriculum mastery. Thus, coaching and mentoring could enhance the competence of teaching supervisors, especially school leaders, particularly in high-performing schools. In turn, this approach will increase the commitment, satisfaction and professional development of teachers leading to improved performance.

Keywords: coaching, mentoring, teaching supervision practices

\section{Introduction}

\subsection{Introduction}

Student achievement in school is often associated with the quality of teachers' instruction in the classroom. This refers to the effectiveness of the teaching delivered by the teacher. Therefore, to ensure that teaching is delivered effectively, teachers must master the curriculum and pedagogy and possess the skills to deliver the lesson's content. However, past studies have shown that there are still weaknesses in teachers' teaching and learning process in the classroom. Among the factors that contribute to the failure of the implementation of teaching and learning in the classroom by teachers are low mastery of teaching contents, one-way and ineffective delivery techniques, lack of teaching preparation, lack of teaching aids, lack of students' engagement in learning and the lack of guidance and assistance when facing teaching-related issues (VC Onyeike \& Nwosu Chinenye Maria, 2018). In addition, students' failure to master the learning content delivered by teachers could be attributed to teachers' weakness during instruction in the classroom teaching and learning process. Thus, guidance from school administrators is very important to discover teachers' potential and improve students' academic achievement.

As outlined by the Ministry of Education, there is a high need for monitoring and supervision from the school to ensure the smooth implementation of the curriculum. Thus, schools administrators, especially principals, should find more efficient mechanisms and solutions to ensure that the teaching done by teachers in the classroom achieves the set objectives. Supervision of principals' teaching is seen as a mechanism that should be implemented in schools to monitor and supervise teachers' teaching on an ongoing basis. This is in line with the instructions from the Ministry of Education Malaysia through the professional circular letter bil.3/ 1987 related to teaching supervision which instructs principals to supervise teachers' teaching to help improve the quality of teaching and develop teacher professionalism. The findings of previous studies show that school administrators are aware 
of the need and importance of implementing teaching supervision in schools to improve teachers' quality of teaching and professionalism.

The teaching supervision practices refer to supervisors' practices when conducting teaching supervision, and the coaching and mentoring approach is seen as the best measure for teaching supervision (Md Said Daimon, 2018). However, there is a need to address questions like 'to what extent do supervisors' ability and effectiveness of teaching supervision depend on the supervisor's teaching supervision approach?' Therefore, this study's objectives have been divided into two components. First, this study aims to identify the extent to which coaching and mentoring approaches are applied by supervisors while implementing instructional supervision. Second, this study aims to explore the extent to which supervisors in schools are ready to implement coaching and mentoring as a practice of teaching supervision.

\subsection{Problem Statement}

Students' academic achievement is often associated with the quality of delivery and the effectiveness of the teaching and learning process in the classroom. Teachers' weaknesses during the teaching and learning process have caused difficulties for students to accept and understand the content of lessons delivered by teachers (Ministry of Education Malaysia, 2016). This happens because the teacher does not master the content or curriculum of the subject well. In addition, students cannot understand the teacher's instruction because the teaching implemented is mostly one-way (Shukri Zain, 2011). This condition is seen as a factor contributing to poor delivery during the classroom learning and learning process.

Evaluation and guidance from school administrators are paramount to improve teaching. Teachers' practices in the classroom need to be monitored and evaluated to detect any weaknesses and suggest improvements. Teaching supervision is seen as the best mechanism in ensuring the quality of teachers' teaching can be improved. However, teaching supervision in schools is less effective because the process is merely done to assess and find teachers' faults (Ahmet Sahin, 2017). Teachers' teaching in the classroom is fully evaluated based on the teaching supervision form provided by MOE. However, two-way discussions between supervisors and teachers to discuss teaching-related matters did not take place. This situation causes teachers to be unaware of the weaknesses in their teaching and, subsequently, unable to improve their teaching.

Teaching supervision based on assessment forms alone does not provide space for a collaborative relationship between supervisors and teachers. This is because there is no specific approach and best practices for teaching supervision. The approach of teaching supervision that seeks out the weaknesses of teachers alone has resulted in the potential and quality of teachers not being able to be developed (Ahmad Kamal, 2016). Supervisors seem to lack the knowledge and experience in teaching supervision practices. This factor is seen as one of the main reasons for the failure to implement effective teaching supervision. This study examines supervisors' understanding of coaching and mentoring approaches as teaching supervision in secondary schools. In addition, this study looks at the extent to which coaching and mentoring approaches are implemented as a practice of teaching supervision in 
secondary schools.

\subsection{State Hypotheses and Their Correspondence to Research Design}

a) What is the level of the supervisor's understanding regarding the teaching and mentoring approach as a teaching supervision practice in secondary schools?

b) How do the coaching and mentoring approach is implemented as a teaching supervision practice in secondary schools?

\section{Literature Review}

The discussions in this section focus on elements such as; i) teaching supervision, ii) coaching and mentoring approach, and iii) implementation of teaching supervision in schools. Each element is discussed as follows:

\subsection{Teaching Supervision}

Teaching supervision is a joint effort made by principals and teachers towards improving the quality of teachers' teaching. As instructional leaders in schools, principals are fully responsible for ensuring that teachers can successfully implement the curriculum in schools as outlined by the Ministry of Education Malaysia (MOE). Therefore, challenges faced by teachers during the teaching and learning process need to be effectively addressed and improved by the principals. Teaching supervision is a requisite to ensure that the curriculum is implemented effectively. MOE circular letter (3/1987) has stated that coaching and mentoring for teachers can be done formally or informally. The MOE has clearly instructed school administrators to implement teaching supervision to improve teachers' teaching quality and ensure the curriculum can be delivered successfully during teaching and learning (Shukri Zain, 2011).

The task of supervising teachers' teaching has been entrusted to middle-level leaders through delegation. These middle leaders comprise the Senior Administrative Assistant, Senior Student Affairs Assistant, Senior Co-Curriculum Assistant, Head of Department and Head of Panel (Hamidah, Jamal \& Sharifah, 2017). Delegation could be the workload borne by the principal. Therefore, the delegation of supervision authority to middle leaders is seen as an appropriate step. to ensure the smooth implementation of teaching supervision in schools,

Teaching supervision allows a supervisor to identify teachers' strengths and weaknesses during instruction. These weaknesses and strengths form the basis of guidance and discussion towards overcoming problems in teaching and, subsequently, improves the quality of teaching (Abebe Tesema, 2014). Furthermore, teaching supervision allows teachers to collaborate directly and face to face with supervisors, especially principals, to discuss problems encountered in teaching. For principals, besides identifying teachers' weaknesses and strengths, teaching supervision is a mechanism to obtain information related to curriculum implementation (Chien-Chin Chen, 2018). The data obtained through teaching supervision could provide important information to assess the effectiveness of curriculum implementation in schools and make further plans to improve curriculum delivery. 
Strategies and approaches adopted when implementing instructional supervision are important in determining the effectiveness of teaching supervision. Teaching supervision implemented without specific strategies and approaches will hinder the achievement of teaching supervision goals ( Zuraidah Abdullah, 2019). Therefore, teaching supervisors need to master specific approaches that could be used in teaching supervision. This is because supervisors who do not have skills in implementing the teaching supervision process will cause teachers to be unsure of the supervisor's ability to help and solve problems in their teaching (Ministry of Education Malaysia, 2016). In turn, this situation will create a negative perception among teachers on the implementation of teaching supervision. The failure of supervisors to implement supervision effectively will hinder the achievement of supervision goals. This could negatively impact the quality of teaching and students' academic achievement (Che Khairuleffendi, Mohd Faiz \& Hapini, 2019).

\subsection{Coaching and Mentoring Approach}

The coaching and mentoring teacher supervision approach combines the elements of coaching and mentoring into the practice of teacher supervision. According to Shukri Zain (2011), the existing teaching supervision process needs to be improved by including elements of coaching and mentoring in line with the current development in education. He further stated that integrating coaching and mentoring with existing approaches could help achieve the real goal of teaching supervision. Therefore, this study discusses coaching and mentoring approaches which form the basis of the study's theoretical framework.

The terms coaching and mentoring are often used interchangeably. However, it is important to distinguish the differences and similarities between coaching and mentoring. First, both approaches require a form of two-way relationship that relies on aspects of trust (Abdul Razak, 2016) in the teacher-supervisor relationship during the process. Hence, supervisors and teachers' full commitment and cooperation will determine the effectiveness of the coaching and mentoring process. Second, the coaching and mentoring approach involves an ongoing relationship between the supervisor and the teacher. This is in contrast with other supervisory approaches where the relationship between the supervisor and the teacher only occurs during the supervisory process. Third, the coaching and mentoring approach requires a longer time to develop teachers' professionalism (Bates \& Burbank, 2019).

The coaching approach is an interactive process between the supervisor and the teacher to solve problems in teaching and improve the quality of teaching. The process involves aspects like the supervisor's giving personal support, technical assistance and encouragement by challenging the teacher to make changes (Abdul Razak, 2016). On the other hand, the mentoring approach involves collaboration between the mentor (supervisor) and mentee (teacher) by providing their expertise. The mentor will use his expertise and skills to guide the teacher to solve problems in classrooms. In this regard, supervisors will be role models for teachers and be a source of reference for solving problems in teaching.

In Finland, coaching and mentoring programmes are highly emphasised and prioritised by school administrators. Novice teachers will be monitored by senior teachers who provide guidance and instruction for effective teaching (Ministry of Education Malaysia, 2016). 


\section{Macrothink}

International Journal of Human Resource Studies

ISSN 2162-3058

2021, Vol. 11, No. 4S

Meanwhile, in South Korea, experienced senior teachers will demonstrate effective teaching methods and techniques to novice teachers (Zahanim \& Qurratu Aini Syamimi, 2018). In addition, novice teachers can also observe classes conducted by senior teachers to help them familiarise themselves with the classroom atmosphere and the learning environment. Mentoring encompasses a supervisor's effort to guide teachers through tried and tested measures rather than encouraging teachers to try something new (Wong Su Huong \& Nur Ain Elzira, 2018). An effective supervisor should be able to skillfully master different approaches in teaching supervision. Hence, the coaching and mentoring approach is an appropriate and comprehensive approach for teaching supervision. However, according to Shukri Zain (2011), teaching supervision without coaching and mentoring may not be comprehensive and will be less effective.

In the context of teaching supervision in Malaysia, a study by Noel Jinbai Anak Balang (2017) showed that administrators still rely on the traditional style of teaching supervision. Teaching supervision mostly focused on assessing teachers' competency rather than teachers' professional development. Therefore, the supervision approaches adopted by the supervisors have little impact on the improvement of teaching quality. On the other hand, many administrators have little exposure to coaching and mentoring approaches as a teaching supervision practice (Bob Garvey, Paul Stokes \& David. M, 2018). Some school administrators stated that due to the novelty of the coaching and mentoring approach, administrators still need to time make some adjustments and learn about it in detail before adopting it to teaching supervision (Chia Swee Yee (2017). Studies also showed that school administrators agree that coaching and mentoring approaches should be applied as a teaching supervision practice (Noel Jinbai Anak Balang, 2017). This is in line with the need to change teaching supervision approaches in line with the development and mobilisation in the education system. Therefore, there is a need to strengthen the teaching supervision system to ensure and ensure the quality of teachers' teaching can be improved so that maximum delivery in the classroom can occur as outlined by the MOE. Overall, the findings of previous studies show that adopting coaching and mentoring into teaching supervision could help improve the quality of teaching and teacher professionalism. Moreover, the coaching and mentoring approach allows supervisors to share their experience and expertise in the field. 


\section{Conceptual Framework}

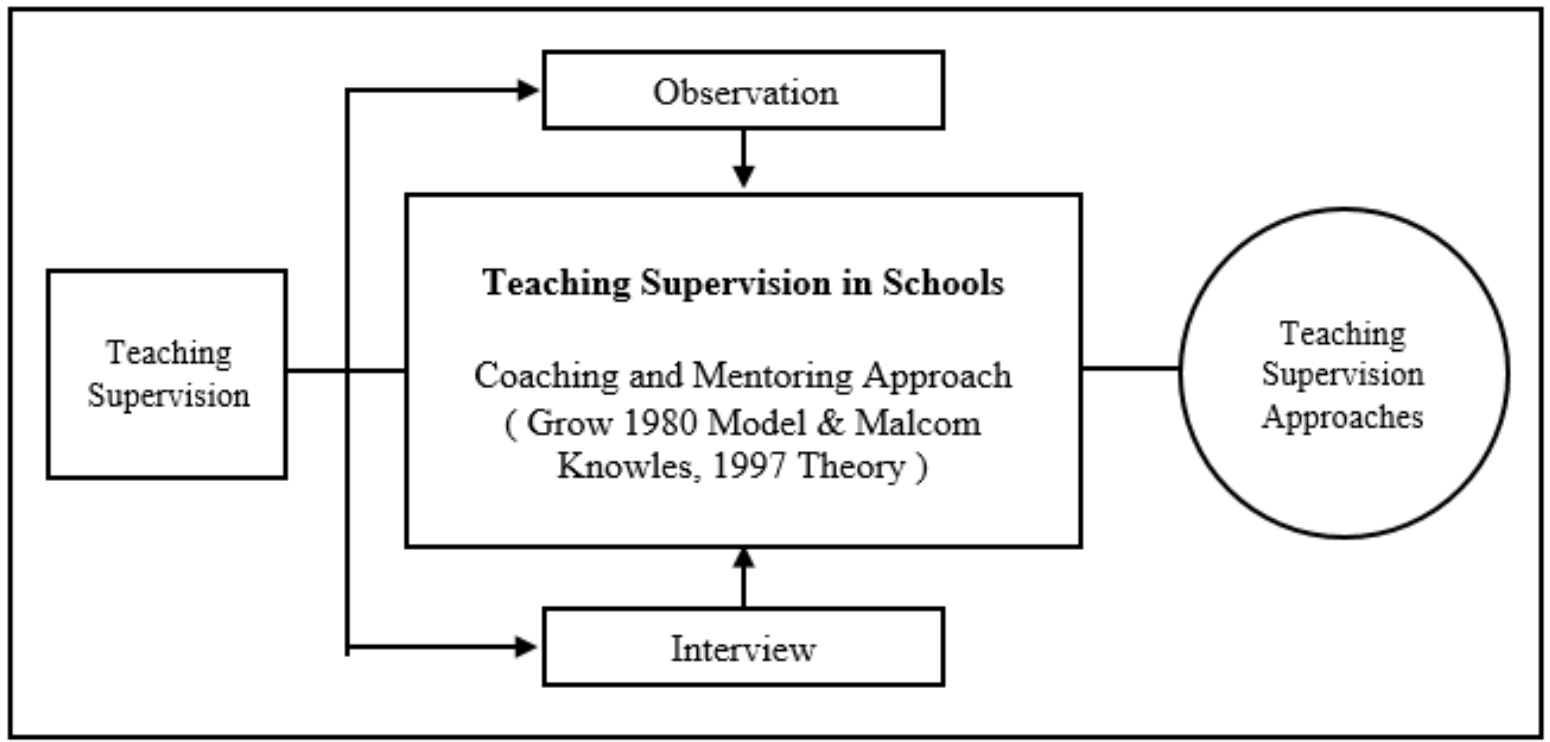

Figure 1. Conceptual Framework of Research

\section{Research Method}

This study used the qualitative research method and applied the case study approach. This study was conducted in several secondary schools in the state of Kelantan. Study participants consisted of school administrators directly involved in implementing teaching supervision in schools. A total of eight study participants were selected through the purposive sampling method. The study participant' criteria are detailed in Table 1. Data collection was done through interviews and observations. The study data obtained were analysed through the constant comparison method encompassing three phases, namely, i) open coding, ii) axial coding, and iii) in-depth reading.

Transcripts of interview data were sent back and reviewed by the study participants themselves to ensure validity and reliability. Next, the interview data and observational data analysed went through expert validation through the Cohen Kappa index. The value of the Cohen Kappa coefficient obtained is 0.89 , which exceeds the minimum value of 0.60 , as recommended by Wheelock et al. 2000 (Monique, Inge Hutter \& Ajay Bailey, 2020). The researchers also implemented the data triangulation method to improve the validity and reliability of the data.

Table 1. The study's participants comprise school administrators

\begin{tabular}{|l|c|c|c|c|c|}
\hline Code & Age & Sex & Position / Grade & Experience & School Location \\
\hline SH/ PPH 1 & 57 & Male & DG 54 & 30 years & Kelantan \\
\hline SH/ PKP 2 & 55 & Female & DG 52 & 29 years & Kelantan \\
\hline SH/ PKH 3 & 55 & Male & DG 52 & 29 years & Kelantan \\
\hline SH/ PKK 4 & 48 & Male & DG 48 & 22 years & Kelantan \\
\hline SH/ PPH 5 & 58 & Female & DG 54 & 31 years & Kelantan \\
\hline
\end{tabular}




\begin{tabular}{|l|c|c|c|c|c|}
\hline SH/ PKP 6 & 56 & Male & DG 52 & 28 years & Kelantan \\
\hline SH/ PKH 7 & 49 & Male & DG 48 & 23 years & Kelantan \\
\hline SH/ PKK 8 & 54 & Female & DG 52 & 28 years & Kelantan \\
\hline
\end{tabular}

\section{Results}

The findings from the analysis of the interview findings and observations on the coaching and mentoring approach in teaching supervision in secondary schools have been broken down into two main parts. The first section discusses supervisors' understanding of coaching and mentoring approaches as a practice of instructional supervision in secondary schools. The second part focuses on implementing coaching and mentoring approaches in teaching supervision in secondary schools. These findings are discussed below.

3.1 Supervisors' Understanding of Coaching and Mentoring Approaches as a Supervisory Practice Teaching in Secondary Schools

Analysis of the study data showed that school administrators who act as teacher supervisors showed an understanding of the elements of coaching and mentoring. Nevertheless, they explained that they had been indirectly exposed to the coaching and mentoring approach. This can be explained through the statements of SH/ PPK 2 and SH/ PKK 4,

“...in fact, coaching and mentoring is not something foreign to administrators in schools ... only the use of coaching and mentoring specifically in teaching supervision is still not highlighted..."

(SH/ PKP 2:50)

“... for me, this thing has been around for a long time ... just rebranding ... if we used to call coaching and mentoring... even at school, there is a mentor and mentee program... in teaching supervision, there is nothing specific ..."

(SH/ PKK 4:67)

The analysis also clarified that school administrators agreed that the coaching and mentoring could be applied specifically in teaching supervision. This is because the approach is seen to help improve teacher teaching quality through collaborative communication between supervisors and teachers. The study participants showed their agreement of this matter as shown below:

“... If the elements of coaching and mentoring are stated specifically in the teaching supervision procedure ... actually good ... I support... but for what way and method do you want the application to need explanation and enlightenment ..." (SH/ PPH 1:82)

“... This approach is good ... because coaching and mentoring involves a continuous two-way relationship... a lot of space and time for discussion sessions between supervisors and teachers ... and not just assessment through forms ... I strongly agree ..."

(SH/ PPH 5: 94)

The Ministry of Education Malaysia should enrich school adminsirtators' understanding of coaching and mentoring. For example, participants of the SH/ PKH 3 study explained that administrators in schools need continuous exposure to coaching and mentoring approaches that can be implemented through teaching supervision. Although school administrators have 
knowledge related to coaching and mentoring, it was never disclosed directly in the process of teaching supervision. This matter was also explained by the participants of the SH/ PKP 6 study through the following statements:

“...I feel that all school administrators should be briefed and given information ... if possible hold a course or workshop to provide information related to coaching and mentoring approaches... how to use and relate in supervision ..." $\quad$ (SH/ PKP 6: 101)

The coaching and mentoring approach is seen as the best platform to produce supervisors who are expert and skilled in the next subject to be a reference for teachers. This is because coaching and mentoring is a form of relationship between an expert and a person who has a problem. The analysis of the study data has shown that the study participants agreed that the coaching and mentoring approach allows supervisors to share expertise to help teachers improve their teaching and resolve issues in the classroom.

\subsection{Implementation of Coaching and Mentoring Approach as a Teaching Supervision Practice in Secondary Schools}

Analysis of the interview and observational data demonstrated that the coaching and mentoring approach is not concretely applied in teaching supervision in secondary schools. Instead, the implementation of teaching supervision is guided by the SKPMG2 form 4teaching supervision. The matter is explained by several study participants as follows:

"... The implementation of supervision at this school, we all follow the guidelines that the MOE has given ... All follow the instruction letter from the NRD ... we value the teachers who teach using the SKPMG2 form ..."

(SH/ PKH 7: 108)

"... There is an actual guide ... we as supervisors need to follow the items in the SKPMG2 form .. teaching teachers will be evaluated based on the criteria ..."

(SH/ PPH 3:60)

The findings showed that the coaching and mentoring did not occur during the teaching supervision session. Collaborative discussions between supervisors and teachers to identify and obtain views related to teacher teaching also did not occur. The focus is examining teacher's journey and classroom practices through a scoring scale in the supervision form. $\mathrm{SH} / \mathrm{PKH} 7$ explained that supervision focuses on determining whether teachers have implemented the standards outlined in SKPMG2 standard 4. The participants also explained that they did not have enough time to hold discussions with teachers afterwards. As a result, they are not able to plan any follow-up action after teaching supervision. This can be seen through the statements of the study participants as follows:

“... It should be like that ... we have to have a response between the supervisor and the teacher .. discuss the teacher's teaching ... but to do all that requires more time ... time constraints are actually on our side as administrators .. so if there are a few weaknesses, it's ok ... the important thing is that the teacher succeeds in implementing PdPc ..."

(SH/ PKP 2: 53)

“... I admit that direct coaching after the end of supervision does not happen ... let alone as 
you explain .. the elements of coaching mentoring ... because to me, if the teacher does everything as in the supervision form ... then there is no need for further action... if you want to say that everything the teacher teaches is perfect, it is illogical .. there are weaknesses ..."

(SH/ SH/ PPH 5: 96)

Effective implementation of coaching and mentoring in teaching supervision requires supervisors, especially school administrators, to prepare and understand its elements. Therefore, there is a need to empower administrators in implementing coaching and mentoring so that teaching supervision can be implemented to improve teachers' quality of teaching and professionalism. However, the participants shared that there is insufficient training, guidance and directive from the MOE over its implementation. Consequently, coaching and mentoring are not implemented in schools' supervision because the MOE do not provide direct instruction and guideline over its implementation. This is in line with participants who shared,

"... We are still using the existing method ... our guide is following the current one, we use the SKPMG2 form ... so far we have not received any instructions to use other approaches ..."

(SH/ PKK 4:70)

“... Actually, we administrators have not been briefed on teaching supervision for a long time ... that's why we still stick to the old method ... if there are any, we received instructions in the form of memos and circulars from JPN or KPM ..." (SH/ PKK 8:111)

Study participants explained that the SISC+ officers from the District Education Office offer to coach and mentor some teachers. These sessions are focused on providing support and guidance for teachers to improve the quality of teaching. However, the coaching and mentoring as part of teaching supervision, especially to school administrators, did not happen. Participant SH/ PPH 1 explained this in the following statement:

“... so far the coaching and mentoring has revolved around SISC + officers ... PPD officers have come down to the school ... collaborated with teachers of certain subjects ... they are there for guidance ... but not all teachers are involved ... if it is specifically for teaching supervision ... so far there is no more ..."

(SH/ PKP 2: 54)

Overall, the data analysis showed that the SKPMG2 teaching supervision form only guides the implementation of teaching supervision based on an evaluation form of teaching based and its scores. In this regard, the coaching and mentoring approach is not applied directly in teaching supervision.

\section{Discussion, Implications and Recommendations}

Understanding coaching and mentoring approaches could help supervisors translate the concept into the real implementation of teaching supervision in schools. This study is consistent with studies by Abdul Razak (2016) and Shukri Zain (2011). The mastery of knowledge related to coaching and mentoring allows supervisors to help improve the quality of teachers' teaching through continuous guidance by using the expertise available to them. Therefore, implementing the coaching and mentoring approach in teacher supervision 
requires understanding and knowledge of its processes. School administrators responsible for teacher supervision in schools should understand that coaching and mentoring is appropriate to improve teachers' teaching quality. In this light, suitable instruments and procedures are necessary for applying coaching and mentoring elements into teaching supervision.

Furthermore, coaching and mentoring during teaching supervision should focus on evaluating teaching and directly observing them in the classroom. Thus, teaching supervision should align with the scoring criteria stated in the SKPMG2 standard 4 instrument. This discussion is in line with the study conducted by Md Said Daimon (2018) that showed that the Ministry of Education Malaysia had set the procedures for implementing teaching supervision. The lack of disclosure related to coaching and mentoring approaches is one of the factors to the non -occurrence of this approach during the teaching supervision process. The delivery and implementation of the coaching and mentoring approach revolve around SISC+ officers who assist certain teachers in the school. This discussion aligns with the study conducted by Noel Jinbai Anak Balang (2017) and Wong Su Huong and Nur Ain Elzira (2018). The coaching and mentoring approach needs to be passed down to instructional leaders as they are the direct group with the teachers in the school. Therefore, implementing the coaching and mentoring approach through teaching supervision is seen as appropriate to help improve the quality of teaching and further develop the professionalism of teachers to a more excellent level.

\section{Conclusion}

The effectiveness of the teaching supervision is directly related to the approach used by supervisors in its implementation. Therefore, there is a need for consolidation and strengthening of supervisors' coaching and mentoring approach. This is important as supervisors who lack knowledge and are not skilled in coaching and mentoring will not apply such an approach while supervising teachers. Past studies have proven that the coaching and mentoring approach is the best method to improve teachers' teaching and professionalism. Therefore, teaching supervision approaches should change into a more efficient one and in line with the current development of the education system. In particular, the Ministry of Education Malaysia needs to provide space and opportunities for school administrators to strengthen knowledge, especially related to coaching and mentoring. It is undeniable that coaching and mentoring have taken place in schools; however, the concept of coaching and mentoring is still new, and teaching supervision does not involve the entire school's administrative system. In this regard, the MOE should provide training related to coaching and mentoring approaches to encourage administrators to implement teaching supervision in schools.

\section{References}

Tesema, A. (2014). The practices and challenges of school-based supervision in government secondary schools of Kamashi Zone of Benishangul Gumuz Regional State (Doctoral dissertation, Jimma University).

Abdul, R. A. (2016). Coaching \& Mentoring Dalam Pendidikan. Konsep, Peranan, Proses, 
Membina Kepercayaan, Model dan Praktis. Institut Aminuddin Baki. Bandar Enstek.

Ahmad, K. (2016). Pelaksanaan Amalan Penyeliaan Pengajaran Oleh Kepimpinan Instruksional Dan Hubungannya Dengan Motivasi Kerja Guru Di SMK Harian. Tesis PhD: Universiti Malaya. Kuala Lumpur.

Kayikçi, K., Yilmaz, O., \& Sahin, A. (2017). The Views of Educational Supervisors on Clinical Supervision. Online Submission, 8(21), 159-168.

Bates, A. J., \& Burbank, M. D. (2019). Agency in teacher supervision and mentoring: Reinvigorating the practice. Routledge. https://doi.org/10.4324/9781315225494

Bob, G, Paul, S., \& David, M. (2018). Coaching and Mentoring: Theory and Practice. Los Angeles: Sage.

Che, K, Mohd, F., \& Hapini. (2019). Tahap Dan Perasaan Ketika Penyeliaan Pengajaran Guru: Kajian Di Sekolah Agama Yayasan Islam Kelantan. Journal Of Educational Research And Indigenous Studies, 2(1).

Chia, S. Y. (2017). Coaching Dalam Pelaksanaan Kajian Tindakan Oleh Guru Sekolah. Jurnal Penyelidikan.

Chien-Chin, C. (2018). Facilitation of Teachers' Professional Development Through Principals' Instructional Supervision And Teachers' Knowledge-Management Behaviors. National Chengchi University: Taipei, Taiwan. https://doi.org/10.5772/intechopen.77978

Hamidah, J., \& Sharifah, H. (2017). Aplikasi Analisis Modifikasi Kepentingan Prestasi Amalan Penyeliaan Pengajaran Ketua Panitia Seperti Sedia Ada Dan Yang Diperlukan Oleh Guru. GEOGRAFI OnlineTM Malaysia Journal of Society and Space 12 issue 8 (89-99) () 2016, ISNN 2180-2491.

Kementerian, P. Malaysia (2016). Teaching and Learning International Survey (TALIS) 2013. Bahagian Pendidikan Guru. Putrajaya, Malaysia.

Md Said, D. (2018). Panduan Pelaksanaan Program Bimbingan Di Sekolah Berasaskan SKPMG2. Kementerian Pendidikan Malaysia.

Noel, J. A. B. (2017). Penerimaan Guru-Guru Bahasa Melayu Terhadap Bimbingan Dan Mentoran School Improvement Specialist Coach (SISC+) Daerah Selangau. Kertas Projek Sarjana Pendidikan. Fakulti Pendidikan: Universiti Kebangsaan Malaysia.

Shukri, Z. (2011). Penyeliaan pendidikan: Teori dan amalan. Tanjung Malim:Emeritus Publications.

Onyeike, V. C. \& Nwosu, C. M. (2018). Principals' Administrative And Supervisory Roles For Teachers' Job Effectiveness In Secondary Schools In Rivers State. British Journal of Education, 6(6), 38-49.

Wong, S. H., \& Nur, A. E. (2018). Bimbingan Dan Pementoran Pembimbing Pakar Peningkatan Sekolah (SISC+) Menurut Perspektif Guru Dibimbing (GDB). International 


\section{Macrothink}

International Journal of Human Resource Studies

ISSN 2162-3058 2021, Vol. 11, No. 4S

Jounal of Education, Psychology and Counseling, 3(13). 57-72.

Zahanim, \& Qurratu, A. S. (2018). Konsep Mentoring Dalam Kalangan Guru: Satu Penelitian Awal. E-Prosiding Persidangan Antarabangsa Sains Sosial dan Kemanusian 23-24 April 2018. Kolej Universiti Islam Antarabangsa Selangor.

Zuraidah, A. (2019). The Relationship between Teaching Supervision with Teachers' Motivation in Secondary Schools. Journal of Advanced Research in Social and Behavioural Sciences. ISSN (online): 2462-1951.

\section{Copyright Disclaimer}

Copyright for this article is retained by the author(s), with first publication rights granted to the journal.

This is an open-access article distributed under the terms and conditions of the Creative Commons Attribution license (http://creativecommons.org/licenses/by/4.0/). 